\title{
The Taylor Rule and Financial Stability - A Literature Review with Application for the Eurozone
}

\author{
Benjamin Käfer ${ }^{* \dagger}$
}

\begin{abstract}
The question whether central banks should bear responsibility for financial stability remains unanswered. In connection with the use of interest rates, it is therefore not clear whether and how the Taylor rule should be augmented by an additional financial stability term. This paper reviews the normative and positive literature on Taylor rules augmented with exchange rates, asset prices, credit, and spreads. These measures have evolved as common indicators of financial (in)stability in the Taylor rule literature. In addition, our own analysis describes the development of these indicators for the core and the periphery of the Eurozone. Given the high degree of heterogeneity between euro area countries, the conclusion here is that an interest rate reaction to instability by the European Central Bank would be inappropriate in times of crisis. However, this conclusion is somewhat weakened if there is no crisis.
\end{abstract}

JEL Classification: E52, F33, F42

Keywords: Taylor rule, financial stability, sovereign debt crisis, Eurozone heterogeneity, exchange rates, asset prices, credit spreads

\section{Introduction}

Concerns regarding financial (in)stability have been growing steadily since the start of the global financial crisis in 2007. Whether central banks should be responsible for financial stability in addition to their usual goals is, however, still undecided. This normative debate on monetary policy has been intensive, but to date without reaching a definite conclusion. Proponents argue that a financial stability goal would be a useful supplement to a flexible inflation targeting framework. Moreover, they argue that central banks should actively use the interest rate to lean against the wind of financial

\footnotetext{
* University of Kassel, Department of Economics, Nora-Platiel-Str. 4, 34127 Kassel, Germany; E-Mail: ben.kaefer[at]t-online.de

$\dagger \quad$ This paper benefited from helpful comments by Katharina Käfer, Jochen Michaelis, Jakob Palek and Benjamin Schwanebeck. Further helpful suggestions were made at the 16th Göttinger Workshop "Internationale Wirtschaftsbeziehungen" as well as the MAGKS Colloquium Rauischholzhausen, both held in 2014.
} 
imbalance (see, e. g., WOODFORD 2012). Other prominent researchers are more skeptical, attributing the preservation of financial stability primarily to regulatory instruments rather than interest rates (see, e. g., Svensson 2012). Despite the natural role that central banks might have in preserving financial stability for several reasons (see, e. g., Schinasi 2003), this task is complicated by the fact that financial stability is seen as a public good and ensuring financial stability might conflict with the achievement of other public policy goals (ALLEN and Wood 2006). The legal basis for promoting financial stability should therefore be as clear as possible in order to define the responsibility of central banks and to evaluate their performance. In practice, some aspects of their actions can be ascribed to financial stability considerations. However, for most central banks these links are somewhat vague, and vary greatly from one central bank to another. Contrary to the generally agreed objectives of price and output stability, financial stability is rarely seen as an explicit policy objective within their statutes (OOSTERLoo and DE HAAN 2004). This topic has, however, recently gained importance in the debate on whether central banks are still acting within their mandates. It is sometimes argued that since financial stability serves as a precondition for monetary and macroeconomic stability, no explicit formulation of such an objective is required to act within statutory limits (BAXTER 2013).

Consequently, this unresolved normative discussion also extends to policy implementation. For two decades, interest rate setting has tended to be illustrated by policy rules based on the famous work of TAYLOR (1993). Taylor rules concerned with price and output stability are now widely acknowledged. However, the growing concerns in recent years about financial stability raise the question whether central banks could pursue such a goal, and if so, how. A large body of literature on central banks actions focuses on the inclusion of various kinds of stability measures in the Taylor rule. This paper gives a structured and detailed review of these stability measures in the context of the Taylor rule.

This survey contributes to the existing literature on the Taylor rule in two important ways. To begin with, it is the first attempt to give a structured overview on the possible range of financial stability measures employed in the Taylor rule. This is done in four subsections: exchange rates, asset prices, credit or leverage, and credit spreads. We first review very basic and also some supplementary theoretical papers in each subsection. In addition, a review of selected empirical papers is provided. Because of the enormous volume of literature that has been published in this field, this survey is inevitably selective in order to derive the main conclusions. Second, we evaluate the stability measures in relation to the Eurozone and in the light of the ongoing sovereign debt crisis. Central banks seem commonly to react to financial instability with interest rate cuts. Hence, we ask whether a special measure could have been a useful guide to the European Central Bank (ECB) during their recent interest rate setting. Looking at the empirical development in each subsection, our findings are clearly time dependent. There would have been little or no benefit for the ECB to be guided by those main measures of financial (in)stability in times of crisis as developments across euro area countries have been too heterogeneous. While many price- 
based stability indicators have shown pronounced boom-bust-tendencies on the Eurozone periphery, they have until recently been fairly stable at the core, especially in Germany. This finding supports discretionary monetary policy in times of crisis. It is, however, weakened in more stable times with only minor disruptions inside of the Eurozone. At least stock price movements across Europe have exhibited a high degree of homogeneity, thus supporting a rule-like preemptive reaction to this measure. This part of the paper shares some elements of the financial integration literature, ${ }^{1}$ especially the price-based investigations of stock prices and sovereign spreads. However, although it is also a common finding in this literature that financial integration is in general time-varying, it is not within the scope of this paper to answer explicitly the question of whether European financial markets have become more integrated or segmented in recent years.

The paper is structured as follows: Section 2 reviews the main arguments in the normative debate concerning whether central banks should bear responsibility for financial stability. It also gives a very brief description of the Taylor rule to explain its functioning in the light of financial stability considerations. Section 3 then reviews the scientific literature on Taylor rule extensions incorporating financial stability concerns among the described subsections and evaluates these measures in the light of their practicability for the Eurozone. Section 4 provides conclusions.

\section{Monetary policy, financial stability, and the Taylor rule}

Considerations about financial stability in monetary policy are nothing new. And yet, there is no generally acknowledged definition of financial (in)stability. This presumably reflects the wide range of central bank responsibilities with respect to financial stability, spawned in turn by the uncertainty prevailing in the normative debate on whether this should be an explicit central bank objective. Nevertheless, it is at least necessary to define what is meant by this term in this paper. ${ }^{2}$ We follow the definition given by ALLEN and WoOD (2006) as their proposal seems most appealing for our purposes. They define financial instability as episodes in which many entities suffer from a financial crisis outside their sphere of responsibility. This crisis is not necessarily financial in origin. What is more, the crisis has to have adverse macroeconomic effects. Financial stability is then given when a crisis is improbable. The definition might be criticized as being too broad, but it is precisely this feature that makes it attractive, because it works without being overly specific about the causes of instability. Financial instability is multifaceted and thus elusive. Against this background, the

1 See, e. g., BAELE et al. (2004) and ECB (2013) as very basic works in this strand considering a broad spectrum of financial submarkets.

2 Another thorough discussion on the range of possible definitions is provided by Issing (2003), who claims that the chosen definition also predetermines the actions the central bank is allowed to take. 
measures addressed in the remainder of this work (as well as their possible modifications) have been developed as the most tangible stability indicator subset. Because of the broad spectrum of financial submarkets they cover, they need a flexible working definition of financial stability.

The role of financial stability considerations in monetary policy can be roughly divided into two separate views: The first view, which is often labeled the conventional or reactive view, is represented for example by BERNANKE (2002) and POSEN (2006). According to this view, the best a central bank can do is to focus on price stability and output stability. In this way, they are already reacting to 'all relevant information'. Crisis prevention is a task for regulatory instruments rather than the interest rate. If financial imbalances nevertheless occur, the central bank is asked to clean up afterward. The second and opposing view, known as the alternative or proactive view, is represented for example by Borio and White (2004), Roubini (2006), and WoODFORD (2012). Authors favoring this view question whether all relevant information is already included in the forecasts of inflation and output. ${ }^{3}$ Furthermore, they regard price stability as a necessary, but insufficient condition for financial stability. While stable prices in recent years did not prevent financial instability from occurring, it is hard to imagine a stable and well-functioning financial system without price stability. ${ }^{4}$ Hence, central banks should actively lean against financial instability.

What is especially interesting about this debate is that authors representing both views employ almost the same arguments - albeit from different sides and with varying emphasis. According to the aforementioned authors, which view one prefers depends, as almost always in economics, on underlying assumptions. The arguments most frequently used are as follows: ${ }^{5}$ The first concern is the identification of financial imbalances. Proponents of the conventional view argue that it is not possible to detect a bubble with certainty, and hence there should be no leaning against the wind. The advocates of the alternative view, however, emphasize that it is not necessary to know whether there is indeed a bubble. According to them, it suffices to know roughly whether there is a buildup of imbalances that could be addressed by monetary policy. In addition, it would be no more complicated to identify financial imbalances than to estimate the output gap correctly. The second common argument relates to the influence of the central bank on financial instability. From the conventional viewpoint, it is often argued that the interest rate would be too blunt an instrument to

3 Forecasting relations of different measures for inflation and output are unstable (see, e. g., Stock and Watson 2003). Assenmacher-Wesche and Gerlach (2010) interpret this as evidence against the proactive view. However, this is not necessarily the case as considerations of financial stability are more than just worrying about inflation and output. Hence, their attempt to forecast 'adverse macroeconomic conditions', defined as strong deviations in output and inflation does not solve this problem.

4 See also Issing (2003) for an evaluation of this debate.

5 This assessment is clearly subjective. More detailed overviews with additional arguments for each side are given by AgÉnor and Pereira da Silva (2012) and White (2009). 
address specific imbalances, which means that it is questionable whether the interest rate can have any influence on specific parts of the financial markets. The opposing view is that an economy-wide rise in the costs of external finance would be adequate to avoid further growth of instability, without addressing isolated market segments. The third argument, which is closely connected to the second one, is about the costs and benefits of monetary intervention. The argument against a monetary reaction is that often the rise in the interest rate needs to be quite high in order to have an influence on financial markets, which could in turn cause high fluctuations in inflation and output. ${ }^{6}$ The proactive counter-argument instead emphasizes on the one hand that not every interest rate rise has to be followed by an economic recession, while on the other hand refraining from a monetary policy reaction would produce even higher costs further down the road, even in terms of inflation and output. Based on these arguments, the authors from both sides have different preferences regarding the use of monetary policy to deal with financial (in)stability.

Authors such as Issing (2011), White (2009) and Woodford (2012) argue that the pre-crisis consensus, dominated by the conventional or reactive view, seems to have been eroded. Since the U.S. subprime crisis and the European sovereign debt crisis, the proactive view of monetary policy and financial stability has gained many proponents. Thus, it seems clear to many authors that if central banks care about financial stability more than already mirrored in output and inflation, then simple policy rules might no longer suffice.

The starting point for the relation between monetary policy and financial stability is the famous policy rule of TAYLOR (1993). According to his rule, the central bank sets the interest rate $i_{t}$ depending on the equilibrium real interest rate $\bar{r}$ and the inflation rate $\pi_{t}$. In addition, the bank considers the distance of the inflation rate from the desired inflation target $\pi^{*}$ and actual output $y_{t}$ from target $y^{*}{ }^{7}$ This is represented by equation (1), where $\alpha$ and $\beta$ are the respective weights:

$i_{t}=\bar{r}+\pi_{t}+\alpha\left(\pi_{t}-\pi^{*}\right)+\beta\left(y_{t}-y^{*}\right)$

Assigning weights of 0.5 to the inflation and output gap as well as an inflation target of $2 \%$, Taylor shows that his rule fits the behavior of the Federal Reserve from 1987 to 1992 reasonably well. However, as CLARIDA et al. (1998), among others, point out, it is the real interest rate that matters in economic decisions, and the central bank can

6 Among others, Assenmacher-Wesche and Gerlach (2010) show in the latter part of their paper that monetary policy can influence asset prices, but this influence is small relative to the movements triggered in inflation and output. Hence, they are skeptical about using the interest rate to lean against financial imbalances.

7 Strictly speaking, Taylor uses the lagged inflation rate over the previous four quarters. Being aware of the fact that this is a simplification, we consider a Taylor rule depending on the current rate of inflation as well as the current output gap. As we have undertaken no empirical or theoretical exercises of our own, this seems to be justified. 
influence this rate in the presence of nominal wage and/or price rigidities. The real interest rate is given by:

$r_{t}=i_{t}-\pi_{t}=\bar{r}+\alpha\left(\pi_{t}-\pi^{*}\right)+\beta\left(y_{t}-y^{*}\right)$

As Taylor notes, the policy implications are as follows: If $\pi_{t}>\pi^{*}$ or $y_{t}>y^{*}$ (or both), then $r_{t}>\bar{r}^{8}$. In this case, the central bank should raise the nominal interest rate to slow the economy. Of course, this mechanism also works the other way round. However, Taylor also remarks that this rule need not be followed mechanically in practice.

The Taylor rule has been the subject of debate for two decades, but it is beyond the scope of this paper to mention all possible directions of thought. ${ }^{9}$ A relevant question for this paper is whether the Taylor rule has any normative meaning as the original weights $\alpha$ and $\beta$ were chosen arbitrarily by TAYLOR (1993). However, RoTEMBERG and WOODFORD (1997) show that central banks' loss functions can be micro-founded to derive the optimal reaction of monetary policy. Thus, weights are no longer chosen arbitrarily but depend on the households' preferences, the production technology and the degree of price rigidity to maximize welfare. Hence, although financial stability is not a consideration in their micro-foundation, the Taylor rule may in general be used in the normative debate on whether central banks should respond to financial instability.

Nevertheless, many papers are concerned with some implicit stability issues (see, e. g., Clarida et al. 2000). The first issue (which is not connected to financial stability) relates to the strength of the monetary reaction to inflation. To stabilize the economy, the real interest rate must be raised more than the inflation rate, implying $\alpha>0$. This is known as the 'Taylor Principle'. The second stability issue is already quite close to financial stability considerations. It is about the smoothing of interest rates, which means that the central bank is concerned with the speed of interest rate adjustments. Policymakers are aware of the fact that abrupt interest rate changes might put the stability of the financial markets at risk, and hence set the rate as a weighted sum of the actual Taylor rule rate and the lagged interest rate.

However, these considerations are not the point of this paper. Rather, the issue here is about explicit financial stability considerations in the Taylor rule. Formally speaking, one can augment equation (1) with a term related to some measure of financial stability, which is given by $x$. Here, $x_{t}$ is the actual value of this measure, whereas $x^{*}$ is the respective 'target' value. The weight of this term in the Taylor rule is given by $\gamma$. Hence, the augmented Taylor rule is:

$i_{t}=\bar{r}+\pi_{t}+\alpha\left(\pi_{t}-\pi^{*}\right)+\beta\left(y_{t}-y^{*}\right)+y\left(x_{t}-x^{*}\right)$

8 For the ease of explanation, we abstract from shocks which lead inflation and output in different directions.

9 A recent attempt to give a brief review about the most relevant discussion points regarding the Taylor rule in the practice of central banking is the work of KAHN (2012). A discussion of the advantages and disadvantages of the Taylor rule is given e. g. by KoHN (2007). 
However, what exactly this extension of the rule should look like remains an open question. Although there are now numerous papers that present augmented Taylor rules, it remains unclear which of those measures would be best to safeguard financial stability. As a consequence, several recent papers employ financial stability indices that comprise a wide range of indicators (see, e. g., Albulescu et al. 2013, BAXA et al. 2013 or CASTRO 2011). On the one hand, these papers are appealing because they allow reactions to a wide range of financial imbalances and are thus more realistic. On the other hand, they greatly complicate policy communication and anticipation. As far as this paper is concerned, they also come at the cost of complicating classification. ${ }^{10}$ Furthermore, it is no trivial matter to define a target or equilibrium value for the chosen measure. What, formally speaking, would be the best value for $x^{*}$ ? If these problems could be solved, which weight $\gamma$ should be assigned to the stability measure by the central bank? And finally, might $\gamma$ be time-varying at different stages of a crisis, implying a regime-switching, non-linear reaction by the central bank? These are some of the questions guiding the papers presented in the main part of this work, whose main contribution will be to structure the literature, and then try to assess the challenges faced by the common monetary policy in the Eurozone in the light of these measures. If the ECB decided to react to financial (in)stability via the interest rate, what measure would probably do best? We shed some light on all of these questions below.

\section{Taylor rule extensions}

This section constitutes the main part of the paper. Here, the four main directions of Taylor rule extensions with financial stability considerations are reviewed. The topics are ordered chronologically according to their appearance in the scientific literature. We start with exchange rates in section 3.1 as this was the topic of one of the earliest discussions concerning extensions of the Taylor rule. Closely connected, and probably the most intensively discussed of all the measures, are Taylor rules with asset prices, which are examined in section 3.2. In section 3.3, the focus is on credit and leverage, whose exaggerations tend to be closely connected to asset price bubbles. Both latter subsections have gained renewed interest since the U.S. subprime crisis. Section 3.4, the last section, addresses the role of credit spreads in the rule. This is especially interesting in the light of the current European sovereign debt crisis as

10 Clearly, this also applies to some of the non-index-papers reviewed in this work. These papers consider more than one indicator in their research and are thus assigned to the subsection that fits best. To save space, this is not explicitly referred to in the remainder of the paper. 
elevated spreads might have been one of the reasons for the ECB to cut interest rates recently. $^{11}$

\subsection{Taylor rules with exchange rates}

The interplay between monetary policy and the exchange rate is extensively laid out by Ho and McCauley (2003) for example. First, there is an impact on inflation. The exchange rate determines the price of imported goods as well as inflation expectations. Second, the competitiveness of domestic firms abroad is influenced by the exchange rate. An appreciation in the domestic currency makes foreign products cheaper and domestic products more expensive. Consequently, the demand for domestic products should fall (and vice versa). But it is clear that these two impacts are only linked to the usual arguments of the Taylor rule, inflation and output, and not financial stability. On the one hand, capital flows induced by the exchange rate can trigger credit and asset price bubbles in the inflowing country, which in turn generates the danger of a subsequent collapse (this highlights the connection to subsections 3.2 and 3.3). On the other hand, if firms' or banks' liabilities are sufficiently 'dollarized' (i. e., their liabilities are to a large extent denominated in a foreign currency) and not evenly matched with their foreign exchange assets, then exchange rate depreciations can increase the burden of outstanding debt and eventually force those firms into bankruptcy. Both arguments are able to cause significant financial instability. Based upon these arguments, Ho and McCAuley (2003) conclude that emerging markets are most affected by such fears as they are usually heavily dependent on exchange rate movements. Their conclusion is also supported, among others, by MOHANTY and KLAU (2004) and AizenMan et al. (2011). According to this broad consensus, most of the studies below focus on emerging markets, which in turn implies a limited applicability for the euro area. Thus, it seems reasonable to keep this part of the review as short as possible.

Among the basic theoretical papers that consider the role of the exchange rate in the Taylor rule are Ball (1999), Svensson (2000), and Batini et al. (2003). The main finding of these three papers is that a Taylor rule reaction to the exchange rate

11 This outline does not account for monetary aggregates for several reasons: First, it is generally agreed among most authors that money has lost some of its meaning in monetary policy (see, e. g., Borio and Lowe 2004; Adrian and SHIN 2008). Second, and more importantly, there is no literature strand that explicitly considers the role of monetary aggregates for financial stability. Third, if monetary aggregates are expected to have some meaning for financial stability, then this is implemented via bank balance sheets, where monetary aggregates on the liabilities side mirror credit on the asset side (KIM et al. 2013). As outlined by WOODFORD (2008), it seems more appropriate to account for the initiator of instability directly, which is credit. This conclusion is supported by SCHULARICK and TAYLOR (2012) and the Deutsche Bundesbank (2013), who show that money and credit are not always closely related, especially not in financial crises. 
seems advantageous for the central bank. Nevertheless, BALL (1999) and BATINI et al. (2003) highlight that the weight given to the exchange rate should be considerably smaller than that given to inflation and output. Moreover, all three papers reach their conclusions with respect to rather conventional loss functions, which are not extended with the exchange rate itself.

This basic normative work is supplemented by several authors. Among them is Adolfson (2007). Applying basic as well as exchange rate adjusted Taylor rules with common coefficient settings, she shows that exchange rate inclusion yields slight improvements compared to basic rules in an inflation/output-oriented central bank. As the pass-through from exchange rates to prices increases so too do the advantages because the impact of the exchange rate change is then transmitted more quickly to prices. Another interesting extension of the basic papers is that of LEITEMO and SöDERSTRÖM (2005), who focus on uncertainty regarding the degree of exchange rate pass-through, the persistence of the foreign exchange risk premium, adaptive exchange rate expectations, and the real exchange rate level. They find that including the exchange rate under the baseline as well as under the uncertainty scenarios improves welfare, but only to a small extent. ${ }^{12}$ WOLLMERSHÄUSER (2006) also considers exchange rate uncertainty but, as probably the most important difference, to a larger degree and finds a more pronounced role for an active exchange rate management. All in all, as pointed out by LeItemo and SöDERSTRÖM (2005) and TAYLOR (2001), a common result in the normative literature seems to be that including the exchange rate in the Taylor rule yields only very slight improvements. ${ }^{13}$

Clearly, all of these theoretical papers, including their conclusions and explanations, ${ }^{14}$ also point to an important drawback for the purpose of this paper: They incorporate only very few, if any, explicit considerations of financial stability. A notable exception is the work of MORÓN and WinKelRIED (2005). They focus on heavily liability-dollarized economies which they classify as vulnerable, and their innovation is the dependence of the entrepreneurs' risk premium on the degree of liability dollarization. According to this, vulnerable countries suffer more from depreciation than they benefit from it. The authors employ six different policy rules to minimize a standard loss function concerned with inflation and output variances. The model shows that Taylor rules augmented by the exchange rate are able to increase welfare. Moreover, the positive effect of the variance reduction is larger in vulnerable economies.

Let us now consider the empirical evidence, which is also reviewed by AIzENMAN et al. (2011). An early indication for active exchange rate stabilization is given by the

12 Leitemo and SÖDerström (2005) obtain the same result as Adolfson (2007) two years later, as both emphasize the growing advantage of exchange-rate-adjusted Taylor rules with rising degrees of pass-through. However, Adolfson also highlights that the inclusion of the exchange rate yields no improvement at all in an optimized model setting.

13 Further interesting normative work supporting this conclusion is given by CЕСCHETTI et al. (2000) and GARCIA et al. (2011) for example.

14 See, e. g., TAYLOR (2001). 
work of CALVO and REINHART (2002). ${ }^{15}$ Their well-known 'fear of floating' hypothesis reveals a divergence between the words and actions of central banks. As unusually low exchange rate volatilities among pretending floaters go along with high volatilities in reserves and interest rates, the authors conclude that there is active exchange rate management in a number of countries, especially in developing ones. Their findings are supported by MOHANTY and KLAU (2004), whose own empirical investigation of 13 emerging markets shows a negative correlation between interest rates and exchange rates, and a strong reaction to exchange rates in augmented Taylor rules. A more recent paper is that of AizenMAN et al. (2011). Their Taylor rule regression tests data for 16 emerging markets from 1989 to 2006 and confirms significant reactions by the central banks to the exchange rate. This feature is particularly strong in non-inflation targeting countries as well as in commodity exporting countries. Regarding the strength of the response, it is always smaller than the reaction to inflation, even if this dominance is not very pronounced in non-inflation targeting countries.

So, what is the consensus? As mentioned above, the normative literature mostly suggests small reactions of the interest rate to the exchange rate. This finding seems to be supported by the positive literature, as this usually states significant, albeit rather small responses. Let us therefore now turn to the Eurozone and reflect on what these findings imply for the common monetary policy of the ECB. The literature reviewed above can be interpreted as a first hint that an exchange rate objective for the ECB would be inappropriate as the Eurozone as a whole is anything but a small and emerging economy (see also GASPAR and IsSING 2002). We try to back this interpretation with some empirical evidence on European banking dollarization as this is one important exchange rate aspect connected to financial (in)stability. The existing literature on dollarization is also primarily concerned with emerging economies and is thus not fully applicable to an analysis of developed euro area countries. Our own research starts with figure 1, which shows the external liabilities to creditors from outside the euro area for euro area banks, normalized to 100 at the end of January in 1999 to make them comparable across countries. ${ }^{16}$ To keep the graphical analysis manageable, we focus on the periphery of the euro area and show only the indices of Greece, Ireland, Italy, Portugal, and Spain compared to the most important core countries, France and Germany. This picture shows a remarkable degree of heterogeneity across

15 Of course, there have already been earlier attempts to estimate the reaction of interest rates to exchange rates; for example, Clarida et al. (1998) claim that the Bundesbank and the Bank of Japan reacted to the exchange rate, but only to a small extent.

16 From the literature on banking dollarization, it is clear that asset dollarization also matters to banks. A transfer of dollarized liabilities into dollarized assets hedges the bank itself against currency risk but leaves it vulnerable to the credit risk of their debtor, who is now exposed to the currency risk (see, e. g., Arteta 2003, De Nicoló et al. 2005, or Levy Yeyati 2006). Nevertheless, in what follows the focus is on liability dollarization. 
euro area countries, with external liabilities rising most impressively in Ireland and Greece. $^{17}$

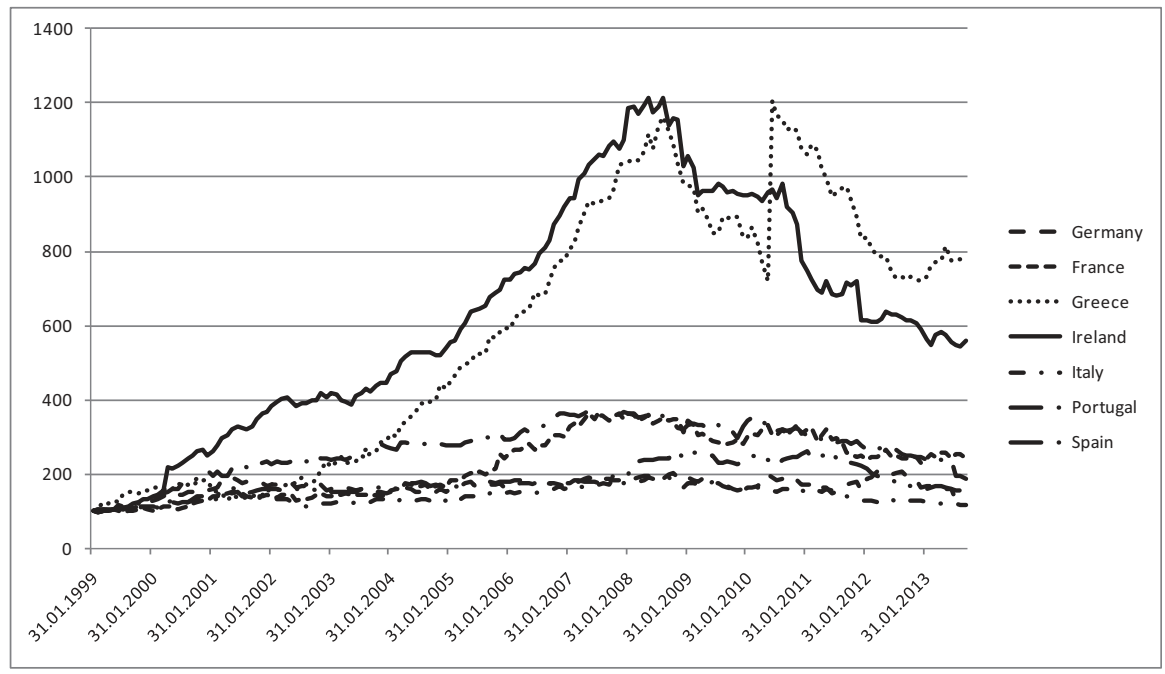

Source: ECB, own calculations

Note: Monthly data normalized to 100 at end of January 1999

Figure 1: External liabilities of the national banking sector

We also computed the relation of external liabilities to the balance sheet total. This share resembles the common working definitions of dollarization in the literature, but it is not equal to them for two reasons. First, as will be shown shortly, external liabilities are not necessarily dollarized. Second, a large part of the literature uses the share of dollarized deposits to total deposits (see, e.g., Arteta 2003, De Nicoló et al. 2005, or Levy Yeyati 2006). However, for ease of explanation and to circumvent classification problems, we rely on the balance sheet total in the denominator. From figure 2, one can see that external liabilities range between $5 \%$ and $20 \%$ of the balance sheet for most of the countries most of the time. A remarkable exception is Ireland, with a share of external liabilities mostly larger than $35 \%$. The conclusion is again that heterogeneity matters.

17 The data for Greece show a very abrupt rise from May to June 2010. We cannot explain this shift, but it does not alter the interpretation of euro area heterogeneity. 


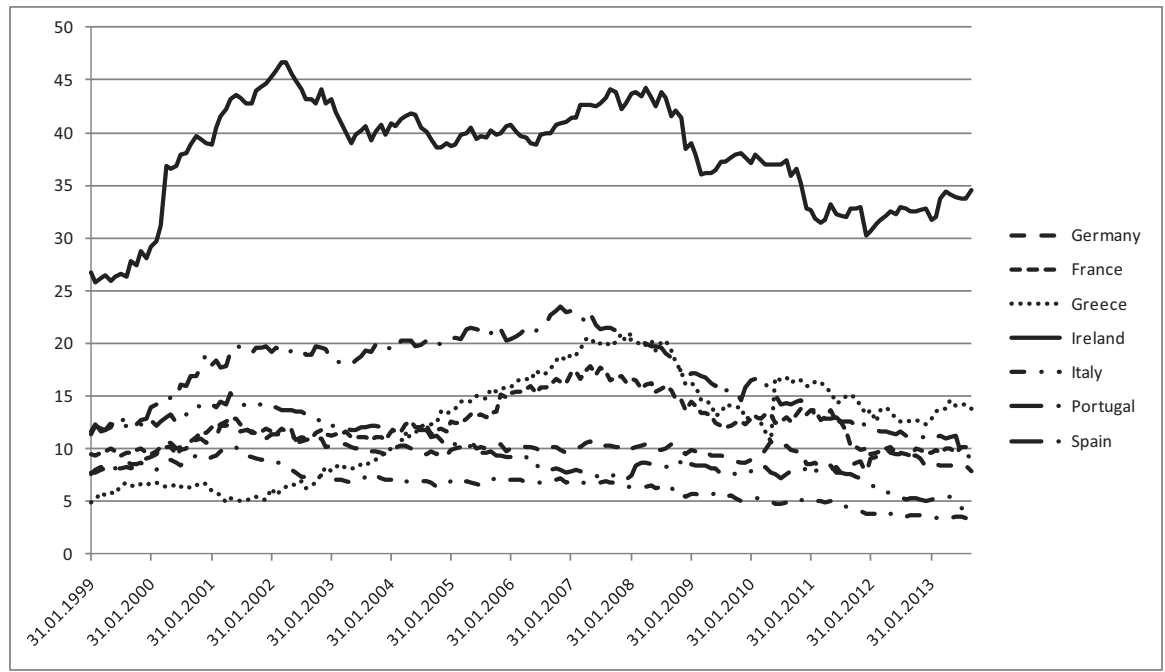

Source: ECB, own calculations

Figure 2: Ratio of banks' external liabilities to balance sheet total (in percent)

Finally, the ECB also offers data on the currency composition of deposit liabilities by European banks. This allows us to draw some conclusions on the importance of foreign currency for those institutions. The results are given in table 1, in which the bandwidth of currency compositions is laid out from early 1999 to mid-2013. First, the euro is by far the most important currency in banking liabilities to other banks as well as to non-banks inside the euro area. Second, deposit liabilities from creditors outside the euro area are also denominated to a considerable degree in euro, albeit to a lesser extent. All in all, table 1 highlights the importance of the euro, especially in internal liabilities, but also in external liabilities. Not surprisingly, the leading role among the other currencies is held by the U.S. dollar, which accounts for approximately two thirds of their share (results not shown here).

Table 1: Currency compositions of euro area banking liabilities

\begin{tabular}{|lccccccc|}
\hline To euro area banks & \multicolumn{2}{c}{$\begin{array}{c}\text { To euro area } \\
\text { non-banks }\end{array}$} & \multicolumn{2}{c}{$\begin{array}{c}\text { To non-euro area } \\
\text { banks }\end{array}$} & \multicolumn{2}{c|}{$\begin{array}{c}\text { To non-euro area } \\
\text { non-banks }\end{array}$} \\
\hline Euro & $\begin{array}{c}\text { Other } \\
\text { currencies }\end{array}$ & Euro & $\begin{array}{c}\text { Other } \\
\text { currencies }\end{array}$ & Euro & $\begin{array}{c}\text { Other } \\
\text { currencies }\end{array}$ & Euro & $\begin{array}{c}\text { Other } \\
\text { currencies }\end{array}$ \\
\hline $\begin{array}{l}86.87 \\
\text { to } 93.76\end{array}$ & $\begin{array}{c}6.24 \\
\text { to } 13.13\end{array}$ & $\begin{array}{c}96.10 \\
\text { to } 97.31\end{array}$ & $\begin{array}{c}2.69 \\
\text { to } 3.90\end{array}$ & $\begin{array}{c}36.53 \\
\text { to } 60.98\end{array}$ & $\begin{array}{c}39.02 \\
\text { to } 63.47\end{array}$ & $\begin{array}{c}41.73 \\
\text { to } 59.05\end{array}$ & $\begin{array}{c}40.95 \\
\text { to } 58.27\end{array}$ \\
\hline
\end{tabular}

Source: ECB

Note: Bandwidth of quarterly data from Q1/1999 to Q2/2013 in percent 
Taken together, if external liabilities are only of minor importance to euro area banks, if those liabilities evolve heterogeneously among them, and if the euro is by far the most important currency in their total liabilities, then this implies that an exchange rate objective for the ECB would be not justified to ensure financial stability.

\subsection{Taylor rules with asset prices}

The most intensely discussed subpart of the augmented Taylor rule literature relates to asset prices, usually grouped into stock and house prices. Much of the discussion concerning whether central banks should take responsibility for financial stability in general is put on the same level as the question of whether they should consider asset prices. ${ }^{18}$ However, we do not intend here to evaluate whether this simplification is correct. Before reviewing some of the important theoretical and empirical papers regarding monetary policy and asset prices, it would seem helpful to explain the significance of the latter for the former. First of all, asset prices may have an impact on inflation and output. These relations are outlined and evaluated in much greater detail by Gilchrist and LeAHY (2002), for example. In short, a hike in asset prices increases the wealth of households and this in turn allows them to consume more. On the corporate side and the Tobin's Q ratio, higher stock prices indicate more profitable investment opportunities. In addition, a rise in the value of their assets increases the value they can pledge as collateral, in line with the 'financial accelerator' literature (see, e. g., Bernanke et al. 1999). Hence, their access to external financing improves, which again enhances investment and spending opportunities. As a result, rising asset prices can be an indicator of future inflationary pressures, even if asset prices are not considered to be part of the inflation measure itself. Adding to those ideas, CARUANA (2005) points out that strongly rising asset prices can endanger financial stability, even without threatening price or output stability in the first instance, as they have the potential to form fundamentally unjustified bubbles that can burst further down the road. This could in turn result in a serious economic slowdown. And if these asset hikes are financed by excessive credit growth, they are even more dangerous. ${ }^{19}$

The normative dispute concerning asset prices, monetary policy and financial stability looks very much like a battle over two rounds between BERNANKE and GERTLER $(1999,2001)$ and CECCHETti et al. (2000, 2002). The well-known work of BERNANKe and Gertler (1999) starts the debate. Based upon the financial accelerator approach of BERNANKE et al. (1999), they regard asset prices as financial friction.

18 In contrast to empirical research, the theoretical discussion does not always distinguish between asset prices in general and stocks or housing in particular. Disaggregating assets into its components does not seem to be necessary for this debate.

19 This highlights the well pronounced interplay between financial stability, asset prices and credit aggregates (see, e. g., Agénor and Pereira da Silva 2012, Borio and Lowe 2004, Detken and Smets 2004, and Goodhart and Hofmann 2008). However, credit aggregates are discussed in subsection 3.3. 
Bernanke and Gertler (1999) test the performance of different policy rules in this setting. More specifically, they compare pure inflation targeting policy rules (i. e., the central bank does not react to output in addition to inflation) with versions also including stock prices. Following the simulation of several shocks to this setting, they find that an aggressive pure inflation targeting strategy without any further reaction to stock prices performs best as measured by the impact on the variances in inflation and the output gap. Hence, there should be no further reaction to asset prices than is already included in the inflation measure. However, they are soon answered by the equally important work by CECCHETTI et al. (2000). They claim that it is strongly advisable for central banks to react to asset prices in addition to inflation and output, although they emphasize that central banks should not target them. To demonstrate this, they extend the work of BERNANKE and GERTLER (1999) along several dimensions. The most important of these are the inclusion of an output gap measure in the policy rule, an explicit inflation/output objective function for the central bank that can be minimized to estimate optimal reaction coefficients, and some degree of interest rate smoothing. With those modified assumptions, the results of CECCHETTI et al. (2000) challenge those of BERNANKE and GERTLER (1999) as they show significant advantages of reacting to stock prices in addition to output and inflation. As already mentioned, this is not the end of the story. BERNANKE and GerTLER (2001) respond to the work of CECCHETTI etal. (2000) by pointing out that the latter authors rely solely on one special shock scenario, an exact five-period bubble, and ignore other possible shock properties. BERNANKE and GERTLER (2001) therefore now consider random draws of the shocks as well as a reaction to the output gap. However, they still do not optimize coefficients and find that adding a small response to stock prices may help somewhat in reducing output variance while at the same time increasing inflation variability. They ascribe this result to a temporary adjustment of the real interest rate, which in turn is something to which monetary policy should always respond, not only in the face of stock market volatility. Finally, CECCHETTI et al. (2002) review the debate and reiterate that they never claimed to be targeting asset prices. They do acknowledge, however, that the results depend on the assumptions concerning the underlying shocks. Thus, the authors still believe that reacting to asset prices might be useful, but the reaction should not be mechanical. What is most interesting is that they claim that the two positions do not actually differ that much, which points to a merely semantic problem. As both views recommend the inclusion of asset price information in different ways, the issue of how much 'relevant information' can be detected and how much of this is already included in the inflation and output measure remains unresolved.

Both the proactive and reactive views receive support from several other papers from which implications regarding the appropriateness of rule-like responses to financial imbalances can be derived. Building upon earlier bubble modeling approaches, GRUEN et al. (2005) compare the reactions of proactive and reactive central bankers in different setups of their model (e. g., differing probabilities of the bubble collapsing or endogenous bubble growth). Their result is that reacting strongly to asset bubbles 
is in general advantageous for small bubbles, but this advantage becomes questionable as the bubble grows and the costs of a burst increase. Unfortunately, in the early stage, uncertainty concerning the existence of a bubble is especially high. All in all, they emphasize that the optimal response to asset bubbles depends on the characteristics of the bubble process and the perceptions of the central bank, so there is no unique rule for response. The adequacy of policy rules is considered even more thoroughly in Bordo and JEANne (2002). In their scenario, monetary policy is able to influence borrowing by setting the interest rate. Small asset bubbles will presumably not trigger credit crunches, whereas very large asset bubbles would require the central bank to tighten interest rates to such an extent to avoid them that this would itself induce a credit crunch. Thus, the bottom line of their two-period model is that monetary policy should act in a non-linear fashion only in intermediate cases, implying that Taylor rule-like behavior is not appropriate. However, there are also normative papers that do not ascribe a separate role to asset prices in the conduct of monetary policy. Gilchrist and Leahy (2002) build upon and extend the work of Bernanke and GERTLER (1999). They employ shocks to expectations and net worth in a real business cycle model, a New Keynesian sticky price model and a financial accelerator model. They also find that a strong inflation targeting strategy in general keeps the economy close to the desired path.

Having examined the normative work, it is now time to see what the empirical results add to the understanding of this subsection. A starting point is again the work of Bernanke and Gertler (1999). The regressions in the latter part of their paper estimate reaction functions for the U.S. Federal Reserve (Fed) and the Bank of Japan (BOJ) from 1979 on. They conclude that the Fed reacted largely in line with their recommendations, focusing heavily on inflation and also paying some attention to the output gap, but paying little attention to stock returns as the resulting coefficient is small, insignificant, and has the wrong sign. The results for Japan are more mixed as they indicate significant reactions to stock returns, although with different signs for the two subsamples. Whereas the results support stabilization thoughts in the latter period, they seem counterintuitive for the earlier period. At least, this points to further objectives for monetary policy besides inflation and output. Opposing evidence for the U.S. is presented by CECCHETTI (2003). He first counts stock market key words in the Federal Reserve's Open Market Committee minutes and transcripts, and shows that the use of those key words increased considerably in boom times. Building upon this, his regression indicates that the Fed responded significantly and in a stabilizing manner to the excess equity risk premium (i. e., the deviation of the risk premium from its long-run trend), which serves as a measure for asset price misalignments for the period 1990-2003. Comparable results are also reported for Germany and Japan. Further support comes from CHADHA et al. (2004), who show small but significant stabilizing reactions to stock prices for the Fed's and the Bank of England's (BOE) augmented Taylor rule for the period 1979-2000. In addition, they also find slight significant stabilizing behavior for the exchange rate for both countries as well as Japan. They interpret their results as a reaction to both factors from time to time when 
it is necessary to avoid large fluctuations, but not as a systematic targeting. ${ }^{20}$ Concerning the Eurozone, as in all subsections, this exercise suffers from the relatively short time span with only one monetary policy for the whole euro area. A relatively recent contribution that overcomes the data problem is that of BOTZEN and MAREY (2010). They use Eurozone data from 1999 to 2005 to show that the ECB considered stock prices in addition to output and inflation even before the recent financial crises. Adding a stock price measure improves overall regression fit and yields strongly significant results. Moreover, the coefficient is of considerable magnitude although it does not reach the importance of the inflation or output coefficients. All in all, BotZEN and MAREY (2010) interpret this as evidence of an active stock market reaction and, what is more, as an indication of financial stability concerns for the ECB.

In addition to the time-invariant approaches above, the (quite vague) suggestion of a nonlinear reaction to asset prices given by Bordo and JEANNE (2002) and GRUEN et al. (2005) is reflected in more recent empirical research. First of all, BAXA et al. (2013) use time-varying coefficients and find that some central banks reacted to a financial instability index only in times of stress. However, due to the limited identification of stress phases, this finding does not allow conclusions to be drawn on whether monetary policy reacts preemptively to asset price booms. The findings of LEE and SON (2013) are more differentiated with respect to this judgment. They highlight that their estimated time-varying stock price reaction coefficient for the Fed is positive from 1991 onwards, but rises strongly only at the very end of boom periods, suggesting reactions to the stock market in busts rather than in booms. Supporting evidence comes from Hoffmann (2013). Distinguishing between booms and busts via dummy variables in his regression, he finds that the Fed has reacted to stock prices only by lowering the interest rate in busts while not increasing it in booms. In contrast, the ECB has not reacted to stock prices. Thus, both latter papers contain an implicit affirmation of the reactive policy view from the empirical side, at least for the Fed.

To sum up, the only broad consensus in the literature is that asset prices should not be a target for monetary policy and rule-like reactions to them seem inappropriate. ${ }^{21}$ Beyond this, theoretical work does not agree on what significance asset prices should have for monetary policy. Notwithstanding these issues, the majority of em-

20 Further, more elaborate empirical research has been conducted, for example by RiGOBON and SACK (2003) and Fuhrer and Tootell (2008) for the U.S. Both find significant reactions of monetary policy to asset market information and both, but especially the latter, emphasize that this is only to the extent the information impacts on inflation and output. They are supported by SiKLOs et al. (2004) for selected European central banks in the runup to the Eurozone.

21 See also ECB (2005) for this conclusion in addition to the above-cited references. 
pirical work exhibits some reaction of the interest rate to asset prices, although there is some debate on whether this reaction is really in addition to inflation and output deliberations. Unfortunately, this is the question that matters if one wishes to decide whether the central banks show some responsibility for financial market stabilization.

What does this imply for the Eurozone in the light of the market turmoil in recent years? As mentioned in the introduction, the evaluation of stock market measures across countries is a common research topic in the financial integration literature, which has gained particular prominence in the light of the European monetary unification. The general finding of time-varying financial integration is confirmed for the stock market by MYLONIDIS and Kollias (2010) and the ECB (2013), among others.

Explicit financial integration judgments are, however, not intended here. The analysis is therefore limited to descriptive patterns. To proxy for national stock prices, we use the respective general stock indices. ${ }^{22}$ Figure 3 plots these for selected European countries from January 31, 1999 to September 30, 2013, on a monthly basis. The data are taken from Thomson Reuters Datastream for the same range of countries as in the former subsection. Indices are normalized to 100 as of the beginning of 1999. Several interesting features stand out. After rising somewhat unevenly after the introduction of the euro, all indices show a striking co-movement from the middle of 2000 onwards; rising and falling together even through the subprime crisis. From this, we conclude that a rule-like reaction to stock prices might be advisable in times without significant market stress. This feature holds until 2009. From then on, no clearcut picture emerges. While the German index heads towards all-time highs, the indices of France and Spain hover around their baseline value from January 1999. In contrast, the remaining peripheral countries experienced no sustainable recovery after the subprime crisis. Only the Irish index has recently seemed to be able to close the gap on France and Spain.

A similar picture emerges if one looks at house price developments. Although there is some convergence of housing markets in Europe, structural heterogeneity is still a very important issue, making the transmission of monetary policy unequal across countries (see, e.g., CALZA et al. 2013 and ECB 2009). As a consequence, house price booms are primarily seen as a national phenomenon, which leads to the conclusion that the common monetary policy in the Eurozone is not very well suited to combat them (ECB 2009, GoodHART and HoFmann 2008).

22 This subpart of the paper is very similar to the work of the ECB (2013). Certainly, the analysis conducted here is somewhat more detailed as it uses specific countries rather than min-max ranges. 


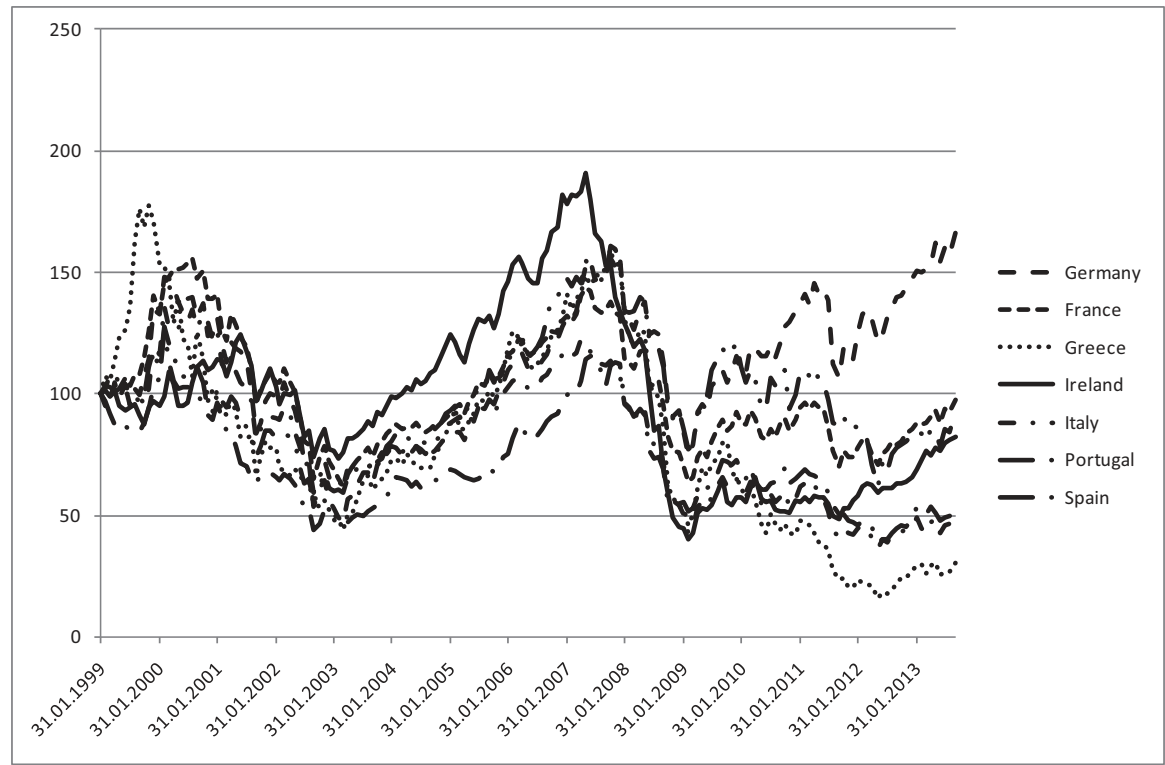

Source: Thomson Reuters Datastream, own calculations

Note: Monthly closing prices of major national stock indices normalized to 100 at January 31, 1999. Indices are DAX 30 (Germany), CAC 40 (France), Athex Composite (Greece), ISEQ 20 (Ireland), FTSE MIB (Italy), PSI 20 (Portugal), IBEX 35 (Spain)

Figure 3: National stock indices

We support this conclusion using recent house price index data compiled by Eurostat on a quarterly basis from 2005 onward. Our research thus extends the work of the ECB (2009), which considers average price developments from 1999 to 2007. The data are normalized by Eurostat to 100 at 2010. Alas, individual time series have different start and end points, which reduces the explanatory power somewhat. ${ }^{23}$ Nonetheless, several interesting conclusions can be drawn from figure $4 .^{24}$ Before 2010 , house prices in most of the countries tend to move around a value of 100 . Notable exceptions are Spain and Ireland, especially with the latter country experiencing a pronounced house price boom. This picture reverses at the beginning of the subprime crisis, with house prices falling in both countries. As the problems in the

23 In general, heterogeneity of house price data across countries and over time is a shortcoming that is also observed by other authors (see, e. g., Goodhart and Hofmann 2008). The data in this analysis are taken from Eurostat, as they seem to be quite well suited for the purpose of this subsection.

24 Our conclusions related to house prices (and later on credit) are also shared by SMETS (2012), who considers euro area imbalances in a broader context. 
Eurozone became an increasing concern for the financial markets from 2010 on, a distinct heterogeneity can be observed in European house prices. Both listing between $70 \%$ and $80 \%$ of the reference value from 2010, Spain and Ireland suffer from remarkable house price corrections. Some declines can also be seen in Italy and Portugal, but the magnitude is smaller. Once again, developments in the core Eurozone are quite different. House prices in France are above the reference value but quite stable in the last two years, whereas house prices in Germany show signs of an incipient boom during the same period.

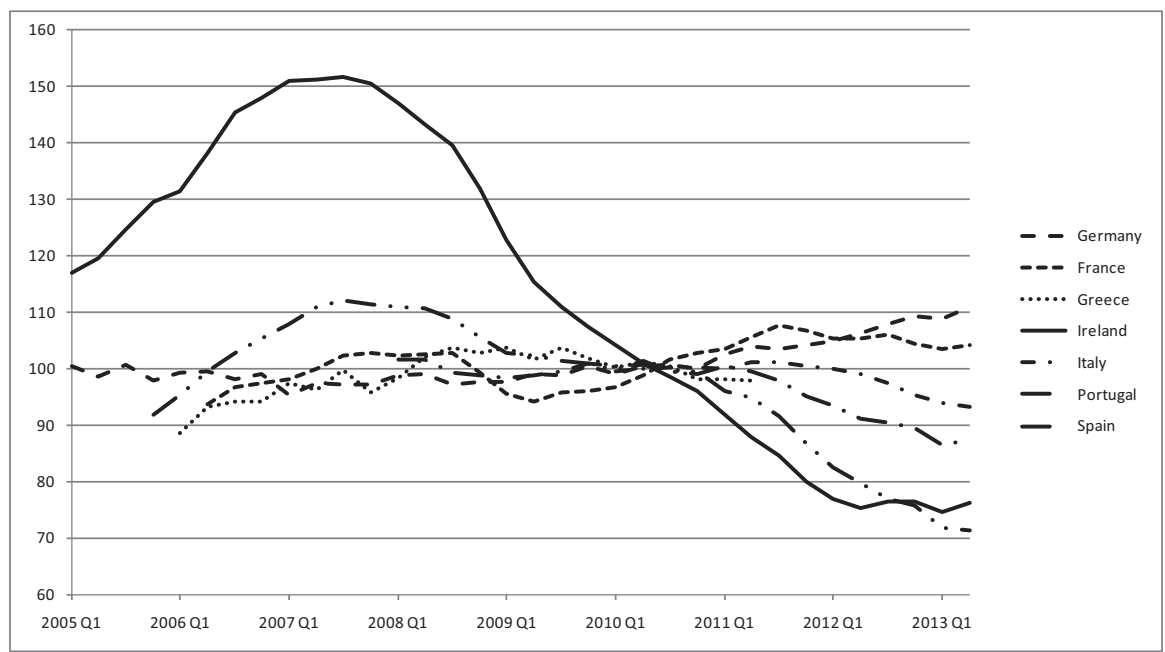

Source: Eurostat

Note: Quarterly house price indices normalized to 100 at 2010

Figure 4: National house price indices

Viewed as a whole, if asset price stabilization from a stock or a housing perspective was one goal of the ECB's interest rate cuts in recent crisis years, this came at the cost of contributing to boosting asset prices in the core of the euro area, with an especially pronounced impact on Germany. Thus, from an asset price perspective, a crisis regime seems to call for discretionary monetary policy.

\subsection{Taylor rules with credit/leverage}

The previous subsection highlighted that asset prices could be of importance to central banks even beyond their implications for inflation and output. However, this might not be the whole story. Some authors argue that asset price bubbles themselves are not the most urgent problem for financial stability. Rather, it is the dangerous two-way interplay between asset prices and credit aggregates that matters. Credit growth can fuel asset price booms but rising asset prices imply higher collateral va- 
lues to boost credit growth (ECB 2005, GerdesmeIER et al. 2010). That is, Borio and Lowe (2002, 2004), Detken and Smets (2004), and Gerdesmeier et al. (2010) ascribe a prominent role to credit in asset price booms, which might then pave the way for costly financial crises. What is more, ADRIAN and SHIN (2008) claim stocks are often held by unleveraged investors, which makes credit - as a closer indicator of instability - even more important from a financial stability point of view. Thus, the following subsection elaborates on the role of credit aggregates more closely. This also allows us to take a closer look at banks, which have once more proven to be of critical relevance to the functioning of the financial system.

There are many theoretical papers that leave a role for credit in the conduct of monetary policy. Three common features of the papers in the normative literature stand out: First, most of them are papers of the dynamic stochastic general equilibrium (DSGE) modeling type, relying on financial frictions such as a collateral channel. Second, many also leave a role for regulatory instruments. This is very important because it is closely connected to the normative discussion concerning the role of the central bank. Nevertheless, the focus here is on the use of the interest rate for stability reasons. Thus, we dwell on regulatory instruments as little as possible in this paper, although we certainly reference work that is also concerned with regulation besides interest rate policy. Third, many authors connect their credit concerns to asset prices, which again highlights the importance of this link. One of these is the work of AGÉNOR et al. (2013). Their model employs a house price shock to generate a credit expansion implied by the built-in collateral/accelerator mechanism. They employ a Taylor rule augmented with credit as well as countercyclical capital regulation to this setting and find that monetary policy is often sufficient to stabilize the economy if it is unrestricted in its actions. Otherwise, for example, if the central bank is interested in avoiding strong interest rate movements, monetary policy should be accompanied by capital regulation. Another paper that relates asset price booms and credit is that of Christiano etal. (2010). They observe that inflation is often low while credit growth is high in stock market booms. Hence, a pure inflation targeting strategy would give no hint to raise interest rates during the boom and might be actually destabilizing. They show this effect by employing a news shock in their setup of the New Keynesian framework. The authors then include an accelerator mechanism in the model, as well as credit growth in the policy rule, and show that the central bank is able to stabilize key components of the economy if it reacts to credit over and above its relevance for inflation. In contrast, GAMBACORTA and SignORETTI (2013) employ a DSGE model with collateral and capital constraints. Reacting to asset prices counteracts exaggerations induced by the financial frictions and thus reduces shockinduced distortions, whereas reacting to credit yields no improvement. In another paper, AYDin and VolKan (2011) test the performance of Taylor rules using the nonfinancial sector borrowing spread, banks' foreign exchange leverage, credit volume, and house prices in their DSGE model calibrated for the Korean economy. They find that reacting to financial instability may be beneficial, but the outcome is shock dependent, with advantages in the case of supply shocks and no improvement when the 
economy is hit by demand shocks. The IMF's (2009) modeling exercise also gives rise to skepticism. They also employ an accelerator mechanism and focus on house price booms. The IMF claims that by responding to financial shocks (a relaxation in lending standards), a credit-augmented rule does indeed outperform the baseline Taylor rule regarding inflation and output variance, whereas in the case of productivity shocks, the standard rule is superior. ${ }^{25}$ Still more skeptical are GELAIN et al. (2013) as they consider the issue of credit and monetary policy in a setting of bounded rationality. A fraction of household decisions are formed by a weighted average between rational and adaptive expectations in the DSGE model. Two results should be mentioned here: First, the hybrid expectations scenario generally increases volatility compared to rational expectations. Second, the results indicate that direct reactions from the central bank either to credit growth or house prices in the policy rule might stabilize some variables, while at the same time increasing the variances of others, e. g., inflation and output. Finally, a very strong position in the normative debate is presented by the recent contribution of BIGGS and MAYER (2013). As credit growth statistics could be biased by the maturity date structure, they demand that the so-called 'credit impulse' be targeted. This is given by the second derivative of credit and thus describes the change in credit growth. Assuming that it is new borrowing that matters for the economy, the credit impulse could serve as a substitute for the output gap, which suffers from well-known estimation problems. In this way, they question the usual claim that credit should be considered, but not targeted (see, e. g., Borio and Lowe 2002, 2004). Monetary policy would then be extended to financial stability as an intermediate target, and may even be simplified.

The work of BORIO and Lowe (2004) is probably the most influential empirical paper concerning the role of credit for monetary policy. After showing the high predictive content of credit volume and asset prices for financial imbalance, the authors augment a Taylor rule with credit gaps and equity gaps for the U.S., Australia, Japan, and Germany. The results are heterogeneous among those countries, with the clearest evidence for some financial stability considerations in the case of the U.S. Moreover, the reaction seems to be asymmetric, which means that monetary policy seems to react only in busts but not in booms, implying at best a reaction along the line of the reactive policy view. Mixed evidence is also given by CECCHETTI (2003). He includes bank leverage as measured by the ratio of total bank assets to total bank capital, which implies credit as the difference between them. In doing so, he interprets leverage as an indicator for banking system stress. He finds a significant negative reaction for the U.S. as well as for Germany, indicating that monetary policy lowered interest rates in the face of rising leverage. Yet, this reaction is not found for Japan. The importance of bank balance sheets from both the macroeconomic and the financial

25 Shock dependency in a comparable setting is also found by Borvin et al. (2010). Furthermore, the IMF (2009), Boivin et al. (2010) and Gelain et al. (2013) also discuss the role of regulation. 
stability perspective is examined in greater detail by ADRIAN and SHIN (2008). Although most of their results are not very pronounced for commercial banks, they show that the balance sheets of broker-dealers have an important impact on macroeconomic development. In turn, the policy rate is an important determinant of institutes' balance sheets. Based upon these findings, they go on to show that the asset growth regression coefficient, which proxies the leverage of market-based intermediaries, is indeed negative. This means that the Fed funds rate falls as leverage rises. Importantly, this relationship is reversed in times of crisis. ${ }^{26}$ On the whole, the results lead them to conclude that monetary policy and financial stability cannot be viewed as disconnected.

To summarize, there is no clear-cut answer when evaluating the role of credit for monetary policy, either from the theoretical or from the empirical perspective. At the very least, it is widely accepted that credit would serve as a useful amendment to asset prices, i. e., those two measures should not be seen separately. Beyond this, no consensus emerges. Theoretical work highlights the dependence on shock origins and the importance of weights for different policy objectives. Uncertainty along those dimensions influences the outcome and complicates the deduction of the optimal monetary policy, which is even trickier with many policy objectives. This originally demanded a careful and gradual reaction of monetary policy, an issue that was long ago derived from the work of BRAINARD (1967).

Once again, we ask what significance this subsection has for the monetary policy of the ECB in the light of the sovereign debt crisis. Given that bank lending accounts for the vast majority of private sector external finance in the Eurozone compared to the U.S. (see, e. g., ECB 2008), this might naturally be of special interest to central banks. The literature on financial integration is not very helpful in this case as it is largely concerned either with cross-border lending or interest rate dispersion across countries (see, e. g., BAELE et al. 2004 and ECB 2013). Both areas are ill-suited for our purposes at this stage because cross-border lending seems to be an improper choice to evaluate national credit evolution, whereas interest rate dispersion is a feature considered in the subsection on spreads.

To examine empirically the behavior of credit in the euro area, we decided instead to focus on the development of bank lending to the private sector in the respective countries, depicted in figure 5 from January 1999 to September 2013. As the focus in this part of the paper is on the specific development in euro area countries, we abstract from interbank credit. The data have a monthly frequency and are taken from

26 With the results of AdRIAN and SHIN (2008) in mind, CECCHETtI's (2003) conclusion that rising leverage signals rising balance sheet pressure and is thus counteracted by lower interest rates must therefore not necessarily be true. Rising leverage could either be due to eroding equity (which would support his conclusion) or be due to rising asset values, which is still part of a boom. In the latter case, lower interest rates would actually be destabilizing. 
Thomson Reuters Datastream. ${ }^{27}$ Again, a core-versus-periphery analysis is conducted. To make the differing volumes among the countries comparable, they were normalized to 100 as of the beginning of 1999 . Once more, this shows some impressing heterogeneity in the Eurozone. Over time, credit volume rises in all countries, but to extremely different degrees. Beginning with core Europe, credit develops in quite a stable manner. Whereas France more than doubles its lending volume from 1999 (but with quite low volatility), ${ }^{28}$ the rise in the German credit volume is negligible. Credit growth in Italy and Portugal is more pronounced from the introduction of the common currency onwards, but these countries have not experienced a substantial reversal in recent years. However, this is a distinct feature of credit volume in Greece and Ireland. Both countries show a significant boom-bust shape, with credit volume rising strongly until the end of 2008 and then collapsing. Spain also experienced a remarkable boom, but there is a more muted shrinkage in credit after its peak at the end of 2008 .

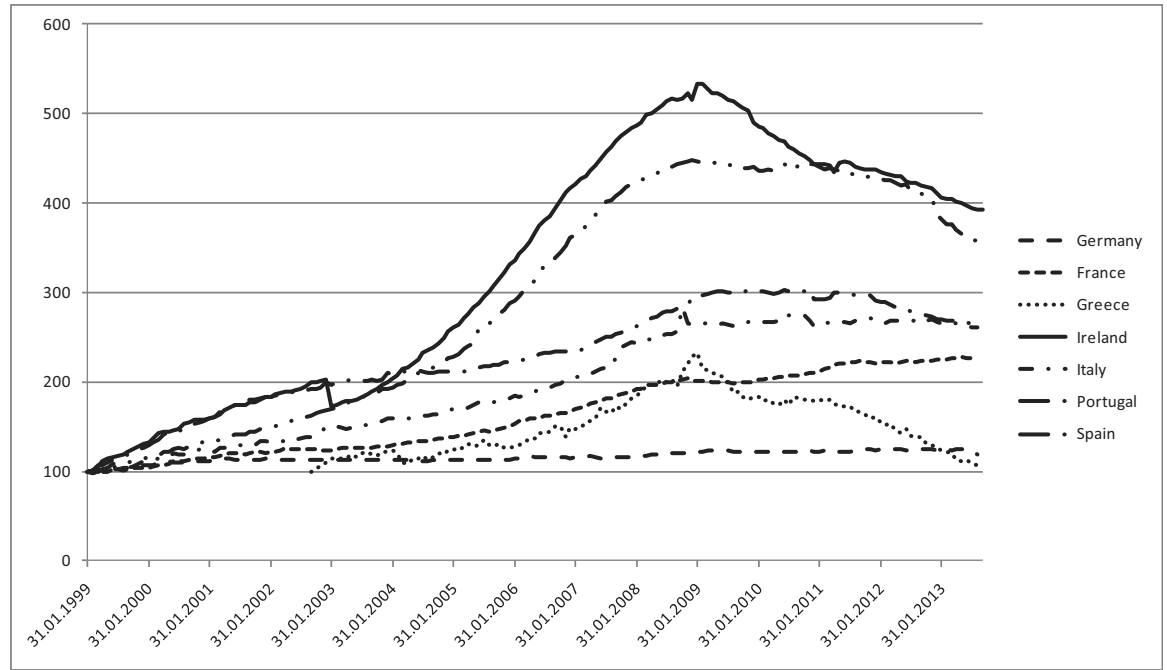

Source: Thomson Reuters Datastream, own calculations

Note: Monthly data normalized to 100 at the end of January 1999 (except Greece, where data are only available from September 2002 on)

Figure 5: Bank lending to the private sector

27 As a robustness check, we also used the data from the ECB's Statistical Data Warehouse, which allows a distinction to be made between household and corporate credit. The results are qualitatively equivalent and thus we do not report them here.

28 We also computed monthly growth rates to gain an intuitive understanding of the volatility of credit development. The results yield relatively more volatility for the peripheral countries compared to Germany and France. Due to space constraints, the figures are not depicted here. 
To conclude, the development of the volume of lending to the private sector has been divergent across euro area countries, again showing some pronounced heterogeneity between core and peripheral countries, both in stable times and times of crisis. This questions once more the adequacy of responding to this kind of imbalances using common monetary policy, and specifically with a Taylor rule. ${ }^{29}$ If credit shows boom-bust shapes in the periphery, would it really be desirable to react, given that development in the core is stable? We do not consider this to be the case. At least, there are no boom tendencies in the core despite the very low interest rates in the recent past. This makes the conclusion somewhat weaker than in the case of asset prices in the former subsection.

\subsection{Taylor rules with spreads}

The most recent strand of stability-oriented Taylor rules augments them with different kinds of spreads. Among these are lending/deposit spreads, corporate spreads and sovereign spreads. The European sovereign debt crisis in particular raised awareness that yield differentials are important as it is not the policy rate that is charged for a credit. Normally, a debtor has to pay a risk premium that reflects ability and willingness to repay the debt. This is where monetary policy comes into play. If spreads rise, for example through changed risk perceptions, the interest burden for the debtor increases. Monetary policy can ease the strain by cutting the policy rate, which acts as an anchor for other interest rates and thus lowers the absolute level of interest rates. What is more, MisHKIN (2009) argues that although monetary policy is not able to reduce valuation risk, its interest rate policy can influence the probability of severe stress to the economy. Thus, he concludes that the central bank can to some extent influence macroeconomic risk and hence the size of the spread.

The short time span since spreads have become an issue is reflected in the relatively small body of normative work in this line of research. The seminal paper that considers spreads and monetary policy is that of CúRDIA and WoODFORD (2010). Based upon the assumption that the Fed's interest rate responses to the subprime crisis could not have been motivated solely on the grounds of inflation and output considerations, they suppose that other indicators could also have been important. As can be seen from subsection 3.3, it might be important to look at financial intermediaries more closely. Thus, they ascribe a role to the rising credit spreads in that time and build a New Keynesian DSGE model that allows for a wedge between lending and deposit rates, justified by costs of intermediation and credit defaults. Monetary policy reacts to spreads in its Taylor rule; i. e., a rise in the spread is answered by lower interest rates. Applying different shocks with differing grades of persistence in their model shows that augmenting the Taylor rule with credit spreads can improve the

$29 \quad$ This finding is also shared in the inspection of heterogeneity in national monetary and credit aggregates in the euro area by the Deutsche Bundesbank (2013), the analysis of which is comparable to but more detailed than that conducted here. 
outcome in terms of inflation and output, but the optimal spread response is clearly case-dependent. In addition, the authors also show that a policy response to credit is dominated by a response to spreads in their setting. With reference to the recent sovereign debt crisis, an interesting extension of the Cúrdia/Woodford-framework is provided by CORSETTI et al. (2013), who include a sovereign spread in the model. This spread impacts on funding conditions in the private sector and is thus preferably to be minimized by the central bank. Certainly, the assumption that monetary policy can always fully neutralize the effects of rising spreads unless it is restricted by the zero lower bound is strong. As a result, the paper's analyses are concerned to a large extent with fiscal policy, on which we do not elaborate here. An interesting exception to the usual inflation/output-loss function is given by the work of TERANISHI (2012). The four equations model allows for two heterogeneous loan contracts representing differing cost channels dependent on distinct external finance ratios. The loss function then includes the spread between those two loan interest rates besides inflation, the output gap and the smoothed policy rate. This setup accounts for differing markups on the policy rate and hence for distortions to the economy. The author concludes that a spread-adjusted Taylor rule constitutes the optimal monetary policy in this setting although the sign of the response to the spread depends on the financial structure, i. e., the detailed properties and the relative importance of each type of loan.

Regarding the empirical aspect, there has also been some emphasis on estimating the reaction of selected central banks to different kinds of spreads. However, most of the empirical spread research is also related to other possible determinants of the interest rate. This research is often conducted via different indices that subsume more than one indicator of financial (in)stability, as was already remarked on in section 2. Thus, classification is difficult. One such study is BelKe and Klose (2010). They separately test the interest rate responses to asset prices, spreads, and money and credit growth by the Fed and the ECB from 1999 to 2007 and from 2007 to 2009. In contrast to many other financial stability indicators, the coefficients for interest rate spreads are consistently negative and significant for both central banks during the normal and the crisis subsamples, indicating a stable response from both central banks to counter rising spreads by lowering interest rates. In contrast, a true indexbased paper is that of CASTRO (2011), who finds significant stabilizing reactions from the ECB from 1999 to 2007 to a financial conditions index consisting of spreads, exchange rates, and asset prices, but no reaction to the sovereign-corporate yield spread in his linear version of the Taylor rule. Interestingly, his results are reversed for the Fed and the BOE, neither of which react to the index but rather to the spread. More work related to spreads is provided by MARTIN and MiLAs (2013). Using subsamples for the U.K. from 1992-2010, the authors find that the BOE's reaction to inflation and output became insignificant and decreased respectively during the subprime crisis. However, adding different spread indices to their framework leads to a better fit and significant coefficients for those indicators in times of stress. From this, they conclude that the BOE tried to stabilize the financial system in times of stress, which is supported by a switching policy rule. Due to the short time span up to now, 
one of the few papers that has estimated the role of sovereign spreads in the current sovereign debt crisis is that of Bouvet and King (2011). Among other features, they estimate the reaction of the ECB to Greek and Irish spreads over German yields. Adding financial stability measures improves regression fit in general, but the results show significant if differing signs for both spreads. Although this sounds counterintuitive, the authors nonetheless ascribe this finding to the different kinds of debt problems the two countries were facing.

On the whole, spreads are certainly the newest field of research among all subsections. This gives rise to some uncertainty regarding the results. The existing normative literature points to the chance of improving the outcome by looking at spread measures, a suggestion that is supported from the empirical side. However, it is unclear to what extent central banks may be able to reduce the spread itself by cutting the interest rate. And even if they were able to do so, they would soon face the problem of hitting the zero lower bound, which would then eliminate the option of further cuts in the future. Unfortunately, this distinction has become very important in the European sovereign debt crisis with its recent elevated sovereign risk premiums and interest rates close to zero. If reducing the interest rate is no longer feasible, this calls for an increasing use of unconventional policy measures irrespective of the comparative advantage relative to interest rate policy. Regarding spreads, a viable option has been the direct purchase of assets, with central banks acting as buyers on the secondary markets. Despite pronounced public doubts concerning legal and implementation issues, operations such as the Securities Markets Programme (SMP) and the Outright Monetary Transactions (OMT) program have been crucial elements for calming down sovereign spreads in the Eurozone, as can be seen below. ${ }^{30}$

To gain an understanding of the magnitude of spreads in the current sovereign debt crisis, we take a closer look at the sovereign bond markets as they have received the most attention during the recent years in Europe. We computed the spread between the 10-year constant maturity bonds of the peripheral countries and France against German sovereign bonds. The results are depicted in figure 6. Again, two interesting features are worth noting. First, starting with some divergence after the introduction of the euro, spreads soon converged and are almost not worth mentioning in the period 2001-2007. The highest value in this time span relates to Greece joining the euro area on January 1, 2001 with a risk premium of around 58 basis points. From 2009, things started to change, and they changed dramatically from 2010 onward. Problems in government finance among the peripheral countries, primarily in Greece, became a concern for financial markets. Spreads in all countries rose until the beginning of 2012, except in Ireland and Spain, where risk premiums peaked in the summer of

30 See the speech of Draghi (2012) and also the questions asked by journalists at the press conference on the introduction of the OMT regarding implementation issues and concerns. Observe also that OMT are not the same as quantitative easing because the ECB (2012) notes that the operations are 'sterilized', i. e., they do not inject further liquidity into the system. 
2011 and 2012 respectively. This finding is also broadly represented by the financial integration literature. Sovereign bond integration is time-varying and there seems to be an underpricing of sovereign risk in the early years of the euro and some sharp reversal in times of crisis (see, e. g., Cipollini et al. 2013 and the references cited therein). From the peaks in 2012 onward, one can see spreads declining in all countries. This implies the second interesting feature, which is even more important for our work. There is still considerable co-movement of spreads, even in times of stress. Although to (admittedly strongly) differing degrees, sovereign spreads moved in the same directions. This feature also holds for the core Eurozone, represented by France, the risk premium of which shows a slight peak at the beginning of 2012 .

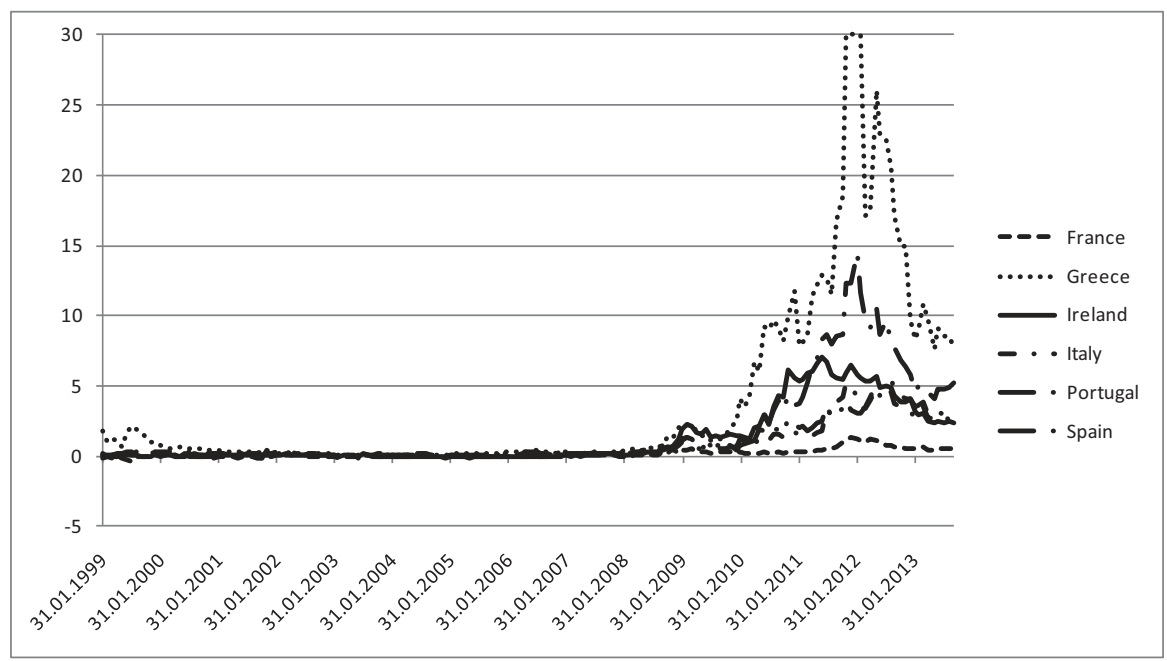

Source: Thomson Reuters Datastream, own calculations

Note: Spreads are calculated on a monthly basis against the respective yield of German sovereign bonds. For ease of presentation, Greek spreads are capped at $30 \%$ to avoid the graphically distortive effects of outliers. The maximum value of the Greek risk premium moves above 55 percentage points on March 1, 2012.

Figure 6: Spreads of 10-year constant maturity sovereign bonds

Thus, importantly, the conclusions from the previous subsections cannot fully be repeated here. As the spreads show some undeniable co-movement, at least in their directions, the common monetary policy seems not necessarily ill-suited to addressing rising spreads, even in times of crisis. Certainly, whether interest rate cutbacks are one or even the only reason for the observed recent spread reductions might be questioned given the fact that the ECB already lowered interest rates massively from the year-end of 2008 onward. Moreover, the aforementioned asset purchase programs presumably also contributed to the observable narrowing of spreads. 


\section{Concluding remarks}

There may well be indications that suggest central banks have begun taking greater responsibility for financial stability in recent years. Nevertheless, most authors conclude that this does not challenge the view that inflation and output remain the primary targets of central banks (see, e. g., BLANCHARD et al. 2010). Another broadly accepted conclusion is that monetary policy should not respond mechanically to financial instability. Certainly, as many authors point out, this was never the intention of Taylor's rule. Alas, the true question of whether financial stability should be an additional objective for central banks still remains unanswered by these conclusions. Rather, it is further complicated by many authors claiming that while central banks should react to imbalances, they should not actually target them. However, it is interesting to note that much of this ambiguity seems to be subject to a semantic problem in the debate concerning flexible inflation targeting, as pointed out by CECCHETTI et al. (2002) and VISCO (2003), for example. But if financial stability is an objective in itself, then the usual dispute concerning whether 'all relevant information' is included in the output and inflation measure becomes irrelevant: there is more than inflation and output! However, the statement that central banks should react to financial (in)stability over and above inflation and output is again questionable when the evaluation is based on the grounds of loss functions that only operate with the variances in the two common measures. This seems surprising as it is common practice in theoretical and empirical work to operate with interest rate smoothing. It is in no way clear why central banks should be concerned about smoothing interest rates which is generally accepted for stability reasons in Taylor rules and also in several loss functions - but not about financial stability itself. There seems to be a logical error, which in our opinion has not received the attention it deserves. ${ }^{31}$

Moreover, based on studies that consider only one economy, the scientific literature is not at all clear whether it is reasonable to take responsibility for financial stability in the Taylor rule over and above inflation and output. For the Eurozone as a whole, the problem is naturally even greater. If one considers the interest rate to be too blunt an instrument at the level of one state (which is micro in this respect), then how could it be appropriate for a whole monetary union (the macro level)? It is one thing to state that 'one size does not fit all', which is a problem that monetary policy always faces, even at the micro level of one state. But this conclusion might become very important if monetary policy is in the rescue mode at a more aggregated level. Saving one member of the union from collapsing inevitably affects the other members and what helps one economy might harm another one, either via the mechanisms considered in this paper or through the manifold problems arising from interest rates near the zero lower bound over a protracted period of time.

31 Cecchetti et al. (2002) express this possibility in a footnote. However, they do not develop the idea further. 
Against this background, we have also analyzed parts of the European financial markets in each of the subsections, claiming that the interest rate reaction of the ECB should be time-varying. There would have been little or no benefit for the ECB to be guided by those main measures of financial (in)stability in times of crisis as developments among euro area countries have been too heterogeneous in the core and the periphery. This clearly negates the adequacy of a rule-like reaction to any of the measures in times of crisis, except for spreads. Such a discretionary reaction might then also avoid the problem of hitting the zero lower bound as a consequence of a rulelike response to instability. However, our results are somewhat weakened in more stable times with only minor disruptions inside the Eurozone. There is at least a great degree of homogeneity among stock price movements in Europe, thus supporting a rule-like preemptive reaction to this measure.

Finally, acting with the intention to stabilize financial markets in a few countries might also harm the most important asset of a central bank, which is its credibility. It is generally not easy for the ECB to explain their actions to the public, given the still quite heterogeneous national transmission mechanisms. Adding financial stability considerations for some countries might further impair transparency and thus render this task impossible.

Evidently, all of these considerations remain interesting fields for further research.

\section{References}

Adolfson, M. (2007): Incomplete exchange rate pass-through and simple monetary policy rules. Journal of International Money and Finance 26(3), 468-494.

Adrian, T. and H. S. Shin (2008): Financial Intermediaries, Financial Stability, and Monetary Policy. Federal Reserve Bank of New York Staff Reports No. 346, September.

Agénor, P.-R.; K. Alper and L. Pereira da Silva (2013): Capital Regulation, Monetary Policy and Financial Stability. International Journal of Central Banking 9 (3), 193-238.

Agénor, P.-R. and L. Pereira da Silva (2012): Macroeconomic Stability, Financial Stability, and Monetary Policy Rules. International Finance 15(2), 208-224.

Aizenman, J.; M. Hutchison and I. Noy (2011): Inflation Targeting and Real Exchange Rates in Emerging Markets. World Development 39(5), 712-724.

Albulescu, C. T.; D. Goyeau and D. Pépin (2013): Financial instability and ECB monetary policy. Economics Bulletin 33(1), 388-400.

Allen, W. A. and G. Wood (2006): Defining and achieving financial stability. Journal of Financial Stability 2(2), 152-172.

Arteta, C. O. (2003): Are Financially Dollarized Countries More Prone to Costly Crises? International Finance Discussion Papers, No. 763, Board of Governors of the Federal Reserve System, March.

Assenmacher-Wesche, K. and S. Gerlach (2010): Monetary policy and financial imbalances: facts and fiction. Economic Policy 25(63), 437-482.

Aydin, B. and E. VolKan (2011): Incorporating Financial Stability in Inflation Targeting Frameworks. IMF Working Paper WP/11/224, September. 
Baele, L.; A. Ferrando, P. Hördahl, E. Krylova and C. Monnet (2004): Measuring European Financial Integration. Oxford Review of Economic Policy 20(4), 509-530.

BALL, L. (1999): Policy Rules for Open Economies, in: Taylor, J. B. (ed.): Monetary Policy Rules. University of Chicago Press, 127-156.

Batini, N.; R. Harrison and S. P. Millard (2003): Monetary policy rules for an open economy. Journal of Economic Dynamics and Control 27(11-12), 2059-2094.

BAXA, J.; R. Horváth and B. VAsíceK (2013): Time-varying monetary policy rules and financial stress: Does financial instability matter for monetary policy? Journal of Financial Stability 9(1), 117-138.

BAXter, T. C. (2013): Financial stability - the role of the Federal Reserve System. Remarks at the 'Future of the Banking Regulation and Supervision in the EU' Conference, Frankfurt am Main, November 15.

Belke, A. and J. Klose (2010): (How) Do the ECB and the Fed React to Financial Market Uncertainty? The Taylor Rule in Times of Crisis. Ruhr Economic Papers No. 166.

Bernanke, B. S.; M. Gertler and S. Gilchrist (1999): The financial accelerator in a quantitative business cycle framework. In Taylor, J. B. and M. Woodford (eds.): Handbook of Macroeconomics, Amsterdam, 1341-1393.

Bernanke, B. S. and M. Gertler (1999): Monetary Policy and Asset Price Volatility. In: New Challenges for Monetary Policy: a symposium sponsored by the Federal Reserve Bank of Kansas City, Jackson Hole, 77-128.

Bernanke, B. S. and M. Gertler (2001): Should Central Banks Respond to Movements in Asset Prices? The American Economic Review 91(2), 253-257.

Bernanke, B. S. (2002): Asset-Price "Bubbles" and Monetary Policy. Speech before the New York Chapter of the National Association for Business Economics, New York, NY, October 15.

Biggs, M. and T. MAYer (2013): Bring credit back into the monetary policy framework! Political Economy of Financial Markets Policy Brief, University of Oxford, August.

Blanchard, O.; G. Dell'Ariccia and P. Mauro (2010): Rethinking Macroeconomic Policy. Journal of Money, Credit and Banking, Supplement to Vol. 42, No. 6, 199-215.

Boivin, J.; T. Lane and C. Meh (2010): Should Monetary Policy Be Used to Counteract Financial Imbalances? Bank of Canada Review, Summer, 23-36.

Bordo, M. D. and O. Jeanne (2002): Monetary Policy and Asset Prices: Does 'Benign Neglect' Make Sense? International Finance 5(2), 139-164.

Borio, C. and P. Lowe (2002): Asset prices, financial and monetary stability: exploring the nexus. BIS Working Paper No. 114, Bank for International Settlements.

Borio, C. and P. Lowe (2004): Securing sustainable price stability: should credit come back from the wilderness? BIS Working Paper No. 157, Bank for International Settlements.

Borio, C. and W. White (2004): Whither monetary and financial stability? The implications of evolving policy regimes. BIS Working Paper No. 147, Bank for International Settlements.

Botzen, W. J. W. and P. S. Marey (2010): Did the ECB respond to the stock market before the crisis? Journal of Policy Modeling 32(3), 303-322.

Bouvet, F. and S. KING (2011): Interest-Rate Setting at the ECB Following the Financial and Sovereign Debt Crises, in Real Time. Modern Economy 2(5), 743-756.

Brainard, W. C. (1967): Uncertainty and the Effectiveness of Policy. The American Economic Review 57(2), 411-425. 
Calvo, G. A. and C. M. Reinhart (2002): Fear of Floating. The Quarterly Journal of Economics 117(2), 379-408.

Calza, A.; T. Monacelli and L. Stracca (2013): Housing finance and monetary policy. Journal of the European Economic Association 11, Issue Supplement S1, 101-122.

Caruana, J. (2005): Monetary Policy, Financial Stability, and Asset Prices. Documentos Ocasionales No. 0507, Banco de Espana.

Castro, V. (2011): Can central banks' monetary policy be described by a linear (augmented) Taylor rule or by a nonlinear rule? Journal of Financial Stability 7(4), 228-246.

Cecchetti, S. G. (2003): What the FOMC Says and Does When the Stock Market Booms. In: Richards, A. and T. Robinson (eds.): Asset Prices and Monetary Policy, Proceedings of the Research Conference of the Reserve Bank of Australia, November, 77-96.

Cecchetti, S. G.; H. Genberg, J. Lipsky and S. Wadhwani (2000): Asset Prices and Central Bank Policy. Geneva Reports on the World Economy 2, International Centre for Monetary and Banking Studies and Centre for Economic Policy Research, July.

Cecchetti, S. G.; H. Genberg and S. Wadhwani (2002): Asset Prices in a Flexible Inflation Targeting Framework. In: Hunter, W. C.; G. G. Kaufman and M. Pomerleano (eds.): Asset Price Bubbles: The Implications for Monetary, Regulatory, and International Policies, MIT Press, 427-444.

Chadha, J. S.; L. Sarno and G. Valente (2004): Monetary Policy Rules, Asset Prices, and Exchange Rates. IMF Staff Papers 51(3), 529-552.

Christiano, L. J.; C. L. Ilut, R. Motto and M. Rostagno (2010): Monetary policy and stock market booms. NBER Working Paper No.16402.

Cipollini. A.; J. Coakley and H. LeE (2013): The European sovereign debt market: from integration to segmentation. The European Journal of Finance, forthcoming.

Clarida, R.; J. Galí and M. Gertler (1998): Monetary policy rules in practice: Some international evidence. European Economic Review 42(6), 1033-1067.

Clarida, R.; J. Galí and M. Gertler (2000): Monetary Policy Rules and Macroeconomic Stability: Evidence and Some Theory. The Quarterly Journal of Economics 115 (1), 147-180.

Corsetti, G.; K. Kuester, A. Meier and G. J. Müller (2013): Sovereign Risk, Fiscal Policy, and Macroeconomic Stability. The Economic Journal 123(566), F99-F132.

Cúrdia, V. and M. Woodford (2010): Credit Spreads and Monetary Policy. Journal of Money, Credit and Banking, Supplement to Vol. 42, No. 6, 3-35.

De Nicoló, G.; P. Honohan and A. Ize (2005): Dollarization of bank deposits: Causes and consequences. Journal of Banking and Finance 29(7), 1697-1727.

Detken, C. and F. Smets (2004): Asset Price Booms and Monetary Policy. ECB Working Paper Series No. 364, European Central Bank, May.

Deutsche Bundesbank (2013): Differences in money and credit growth in the euro area and in individual euro-area countries. Monthly Report 65(7), Frankfurt, 47-64.

DRAGHI, M. (2012): Introductory statement to the press conference (with Q\&A), Frankfurt am Main, September 6, http://www.ecb.europa.eu/press/pressconf/2012/html/ is 120906.en.html\#qa

ECB (2005): Asset Price Bubbles and Monetary Policy. European Central Bank Monthly Bulletin, April, 47-60.

ECB (2008): The role of banks in the monetary policy transmission mechanism. European Central Bank Monthly Bulletin, August, 85-98.

ECB (2009): Housing Finance in the Euro Area. European Central Bank Occasional Paper Series No. 101, March. 
ECB (2012): Technical features of Outright Monetary Transactions. Press Release, September 6, http://www.ecb.europa.eu/press/pr/date/2012/html/pr120906_1.en.html

ECB (2013): Financial Integration in Europe. European Central Bank, Frankfurt.

Fuhrer, J. and G. Tootell (2008): Eyes on the prize: How did the fed respond to the stock market. Journal of Monetary Economics 55(4), 796-805.

Gambacorta, L. and F. M. Signoretti (2013): Should monetary policy lean against the wind? An analysis based on a DSGE model with banking. Bank of Italy Working Paper No. 921, July.

Garcia, C. J.; J. E. Restrepo and S. Roger (2011): How much should inflation targeters care about the exchange rate? Journal of International Money and Finance 30(7), $1590-1617$.

Gaspar, V. and O. Issing (2002): Exchange rates and monetary policy. Australian Economic Papers 41(4), 342-365.

Gerdesmeier, D.; H.-E. Reimers and B. Roffia (2010): Asset Price Misalignments and the Role of Money and Credit. International Finance 13(3), 377-407.

Gelain, P.; K. J. Lansing and C. Mendicino (2013): House Prices, Credit Growth, and Excess Volatility: Implications for Monetary and Macroprudential Policy. International Journal of Central Banking 9(2), 219-276.

Gilchrist, S. and J. V. Leahy (2002): Monetary policy and asset prices. Journal of Monetary Economics 49(1), 75-97.

Goodhart, C. and B. Hofmann (2008): House prices, money, credit, and the macroeconomy. Oxford Review of Economic Policy 24(1), 180-205.

Gruen, D.; M. Plumb and A. Stone (2005): How Should Monetary Policy Respond to Asset-Price Bubbles? International Journal of Central Banking 1(3), 1-31.

Ho, C. and R. N. McCauley (2003): Living with flexible exchange rates: issues and recent experience in inflation targeting emerging market economies. BIS Working Paper No. 130, Bank for International Settlements.

Hoffmann, A. (2013): Did the Fed and ECB react asymmetrically with respect to asset market developments? Journal of Policy Modeling 35(2), 197-211.

IMF (2009): Lessons for Monetary Policy from Asset Price Fluctuations. International Monetary Fund World Economic Outlook, October, Chapter 3.

Issing, O. (2003): Monetary and Financial Stability: Is there a Trade-off? Speech at the Conference on 'Monetary Stability, Financial Stability and the Business Cycle', 28-29 March 2003, Bank for International Settlements, Basel.

Issing, O. (2011): Lessons for monetary policy: What should the consensus be? Center for Financial Studies, CFS Working Paper No. 2011/13.

Kahn, G. A. (2012): The Taylor Rule and the Practice of Central Banking. In Koenig, E. F.; R. Leeson and G. A. Kahn (eds.): The Taylor Rule and the Transformation of Monetary Policy, Stanford, Hoover Institution Press, 63-101.

Kim, H. J.; H. S. SHIN and J. Yun (2013): Monetary Aggregates and the Central Bank's Financial Stability Mandate. International Journal of Central Banking 9(S1), 69-107.

Kohn, D. L. (2007): John Taylor Rules. Speech given at the Conference on John Taylor's Contributions to Monetary Theory and Policy, Federal Reserve Bank of Dallas, Texas, October 12.

LeE, D. J. and J. C. Son (2013): Nonlinearity and structural breaks in monetary policy rules with stock prices. Economic Modelling 31, 1-11.

Leitemo, K. and U. Söderström (2005): Simple monetary policy rules and exchange rate uncertainty. Journal of International Money and Finance 24(3), 481-507. 
LeVy Yeyati, E. (2006): Financial dollarization: evaluating the consequences. Economic Policy 21(41), 61-118.

Martin, C. and C. Milas (2013): Financial crises and monetary policy: Evidence from the UK. Journal of Financial Stability 9(4), 654-661.

Mishkin, F. S. (2009): Is Monetary Policy Effective during Financial Crises? The American Economic Review 99(2), 573-577.

Mohanty, M. S. and M. Klau (2004): Monetary policy rules in emerging market economies: issues and evidence. BIS Working Paper No. 149, Bank for International Settlements.

Morón, E. and D. Winkelried (2005): Monetary policy rules for financially vulnerable economies. Journal of Development Economics 76(1), 23-51.

Mylonidis, N. and C. Kollias (2010): Dynamic European stock market convergence: Evidence from rolling cointegration analysis in the first euro-decade. Journal of Banking and Finance 34(9), 2056-2064.

Oosterloo, S. and J. de HaAn (2004): Central banks and financial stability: a survey. Journal of Financial Stability 1(2), 257-273.

Posen, A. S. (2006): Why Central Banks Should Not Burst Bubbles. International Finance $9(1), 109-124$.

Rigobon, R. and B. SACK (2003): Measuring the Reaction of Monetary Policy to the Stock Market. The Quarterly Journal of Economics 118(2), 639-669.

Rotemberg, J. J. and M. Woodford (1997): An Optimization-Based Econometric Framework for the Evaluation of Monetary Policy. NBER Macroeconomics Annual 12, 297-361.

Roubini, N. (2006): Why Central Banks Should Burst Bubbles. International Finance 9 (1), 87-107.

Schinasi, G. J. (2003): Responsibility of Central Banks for Stability in Financial Markets. IMF Working Paper WP/03/121, June.

Schularick, M. and A. M. Taylor (2012): Credit Booms Gone Bust: Monetary Policy, Leverage Cycles, and Financial Crises, 1870-2008. The American Economic Review 102(2), 1029-1061.

Siklos, P. L.; T. Werner and M. T. Bohl (2004): Asset Prices in Taylor Rules: Specification, Estimation, and Policy Implications for the ECB. Discussion Paper Series 1: Studies of the Economic Research Centre No. 22/2004, Deutsche Bundesbank.

Smets, F. (2012): Imbalances in the Euro Area and the ECB's response. In Allen, F.; E. Carletti and S. Simonelli (eds.): Governance for the Eurozone: Integration or Disintegration? Financial Institutions Center Press, Wharton, 41-59.

Stock, J. H. and M. W. Watson (2003): Forecasting Output and Inflation: The Role of Asset Prices. Journal of Economic Literature 41(3), 788-829.

Svensson, L. E.O. (2000): Open-economy inflation targeting. Journal of International Economics 50(1), 155-183.

Svensson, L. E.O. (2012): Comment on Michael Woodford, 'Inflation Targeting and Financial Stability'. Sveriges Riksbank Economic Review 2012:1, 33-39.

TAYlor, J. B. (1993): Discretion versus policy rules in practice. Carnegie-Rochester Conference Series on Public Policy 39, 195-214.

TAYlor, J. B. (2001): The Role of the Exchange Rate in Monetary-Policy Rules. The American Economic Review 91(2), 263-267.

Teranishi, Y. (2012): Credit spread and monetary policy. Economic Letters 114(1), 2628. 
VISCO, I. (2003): Discussion of 'Asset prices, financial imbalances and monetary policy: are inflation targets enough?' by Charles Bean, Discussion to BIS Working Paper No. 140, Bank for International Settlements.

White, W. R. (2009): Should Monetary Policy Lean or Clean? Federal Reserve Bank of Dallas Working Paper No. 34, August.

WollmershäUSER, T. (2006): Should central banks react to exchange rate movements? An analysis of the robustness of simple policy rules under exchange rate uncertainty. Journal of Macroeconomics 38(3), 493-519.

Woodford, M. (2008): How Important Is Money in the Conduct of Monetary Policy? Journal of Money, Credit and Banking 40(8), December, 1561-1598.

Woodford, M. (2012): Inflation Targeting and Financial Stability. Sveriges Riksbank Economic Review 2012:1, 7-32. 